\title{
New and noteworthy distributional records of treefrogs (Anura) from southwestern Amazonia
}

\author{
Paulo Roberto Melo-Sampaio ${ }^{1^{*}}$ and Moisés Barbosa de Souza ${ }^{2}$ \\ 1 Programa de Pós-graduação em Zoologia, Museu Nacional, Universidade Federal do Rio de Janeiro, Quinta da Boa Vista, Rio de Janeiro, \\ RJ, Brazil \\ 2 Universidade Federal do Acre, Centro de Ciências Biológicas e da Natureza, Rio Branco, AC, Brazil \\ * Corresponding author. E-mail: prmelosampaio@gmail.com
}

\begin{abstract}
We reviewed the herpetological collection of Universidade Federal do Acre and provide here a detailed list of information about new distributional records. We report for the first time in Brazil two anuran species (Dendropsophus joannae and Scinax ictericus) and we extend the known distribution of Dendropsophus marmoratus, Scinax pedromedinae and Teratohyla midas to Acre state. Besides, we provide the second and southernmost record on Scinax iquitorum and new distributional data of Dendropsophus salli from both Acre and Rondônia states.
\end{abstract}

Key words: Acre, bamboo forest, Centrolenidae, distribution, Hylidae

Some Amazonian species of anurans recently described in adjacent countries (Peru and Bolivia) are expected to occur in Brazil (Köhler and Lötters 2001; Lehr et al. 2007; Moravec et al. 2006, 2008, 2009), something that has been confirmed in recent publications (Melo-Sampaio and Souza 2009, 2010; Brown et al. 2011, López-Rojas et al. 2013). However, scarce information on these species is available and materials housed at museums constitute an interesting source of information. Besides, many regions throughout Amazon where species are described in recent years remain poorly surveyed (De la Riva et al. 2000; Moravec et al. 2009; Jungfer et al. 2010). This is particularly true for small hylids and centrolenids widely distributed, but with a scarce number of records (Moravec et al. 2011; Melo-Sampaio and Oliveira 2013; Twomey et al. 2014).

Increase of our knowledge about amphibian faunas of the western portion of the Amazon has been improved during the last years, but considerable inaccuracies have existed regarding the appropriate names for small species of "yellow" treefrogs stored in collections from the upper Amazon Basin. For example, Duellman (2005:
215) stated that frogs referred to as Dendropsophus leali from the Iquitos region of Peru by Rodríguez and Duellman (1994) are in fact D. riveroi, and those referred by them as D. rossalleni correspond to D. leali (De la Riva and Duellman 1997). In order to help the understanding of the composition of western Amazonian anuran fauna, we investigated museum specimens, performed comparisons, and now provide important new records associated with detailed literature.

We examined thematerialhousedat the Herpetological Collection of Universidade Federal do Acre at the city of Rio Branco (acronym hereafter UFAC-RB). We were able to identify new records for Acre state, and also new records for Brazil based on original descriptions and diagnosis, or relevant literature published for all species mentioned here following Bokermann (1964), Duellman and Wiens (1993), Rodríguez and Duellman (1994), Köhler and Lötters (2001), Duellman (2005), Moravec et al. (2009), Jungfer et al. (2010) and Twomey et al. (2014). For each species, we provided localities (municipality and country names) with geographic coordinates, and number of voucher specimens.

We provide below a detailed list of 19 new records from Brazil (18 in Acre and one in Rondônia state) and one new record from Peru. We provide individual collection numbers and a distribution map emphasizing the closest records and type localities of new species recorded from Brazil (Figure 1).

\section{Dendropsophus joannae (Köhler \& Lötters, 2001)}

\section{Figure 2}

Rio Branco: Parque Zoobotânico da Universidade Federal do Acre: 12 individuals (UFAC-RB 0275, 05000505, 0565, 1994-1996, 1998). Senador Guiomard: Fazenda Experimental Catuaba [FEC hereafer]: 11 individuals (UFAC-RB 0551, 0564, 4574-4582). Xapuri: five individuals (UFAC-RB 0652-0656). Mâncio Lima: Parque Nacional da Serra do Divisor [PNSD hereafter]: 


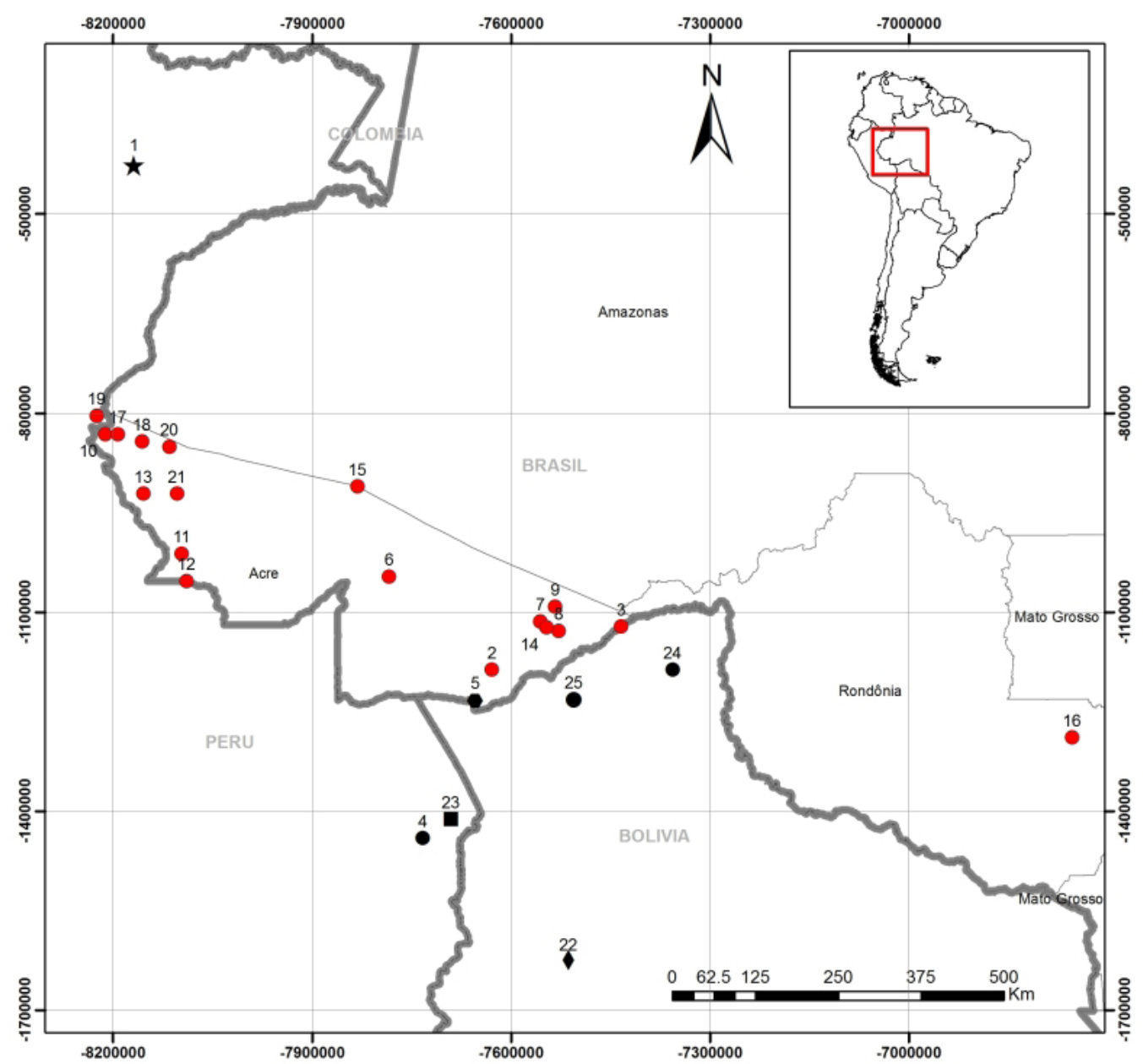

Figure 1. New distributional records to treefrogs species (see text to localities and mentioned species). Star: 1-Type locality of Scinax iquitorum ( $3^{\circ} 49^{\prime} 46^{\prime \prime}$

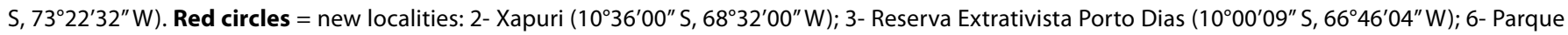

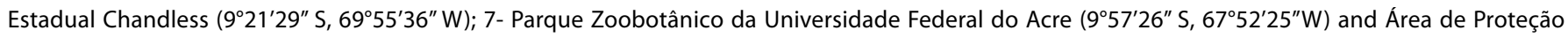
Ambiental Raimundo Irineu Serra; 8- Fazenda Experimental Catuaba ( $10^{\circ} 04^{\prime} 56^{\prime \prime} \mathrm{S}, 67^{\circ} 37^{\prime} 33^{\prime \prime}$ W); 9- Reserva Florestal Humaitá $\left(9^{\circ} 45^{\prime} 03^{\prime \prime} \mathrm{S}, 67^{\circ} 40^{\prime} 20^{\prime \prime} \mathrm{W}\right)$; 10- Igarapé Ramon ( $\left.7^{\circ} 27^{\prime} 00^{\prime \prime} \mathrm{S}, 73^{\circ} 46^{\prime} 00^{\prime \prime} \mathrm{W}\right) ; 11$ - Foz do Tejo and Caminho do Arara ( $\left.9^{\circ} 03^{\prime} 00^{\prime \prime} \mathrm{S}, 72^{\circ} 44^{\prime} 00^{\prime \prime} \mathrm{W}\right) ; 12$ - Foz do Breu $\left(9^{\circ} 25^{\prime} 00^{\prime \prime} \mathrm{S}, 72^{\circ} 40^{\prime} 00^{\prime \prime} \mathrm{W}\right)$; 13- Lago da Pólvora and Santo Antônio ( $\left.8^{\circ} 15^{\prime} 00^{\prime \prime} \mathrm{S}, 73^{\circ} 15^{\prime} 00^{\prime \prime} \mathrm{W}\right)$; 14 - Parque Chico Mendes ( $\left.10^{\circ} 2^{\prime} 14^{\prime \prime} \mathrm{S}, 67^{\circ} 47^{\prime} 35^{\prime \prime} \mathrm{W}\right)$; 15 - rio Jurupari $\left(8^{\circ} 09^{\prime} 00^{\prime \prime} \mathrm{S}, 70^{\circ} 21^{\prime} 00^{\prime \prime}\right.$

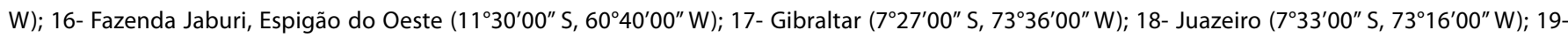

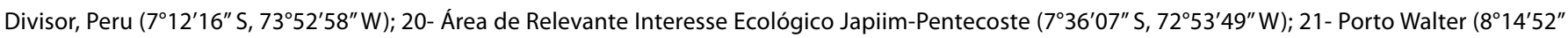
S, $72^{\circ} 47^{\prime} 34^{\prime \prime}$ W). Diamond: 22- Type locality of Dendropsophus salli $\left(14^{\circ} 26^{\prime} 1^{\prime \prime}\right.$ S, $67^{\circ} 29^{\prime} 35^{\prime \prime}$ W). Square: $23-$ Type locality of Scinax ictericus (12 $35^{\prime} 00^{\prime \prime}$, $\left.69^{\circ} 05^{\prime} 00^{\prime \prime} \mathrm{W}\right)$. Black circles are previous sites where Dendropsophus joannae and/or Scinax ictericus/Scinax pedromedinae were known: 4- Tambopata, Peru (12 $\left.50^{\prime} 00^{\prime \prime} \mathrm{S}, 69^{\circ} 28^{\prime} 00^{\prime \prime} \mathrm{W}\right)$; 24- Ribeiralta, Bolivia $\left(11^{\circ} 00^{\prime} 00^{\prime \prime} \mathrm{S}, 66^{\circ} 05^{\prime} 00^{\prime \prime} \mathrm{W}\right) ; 25$ - Nacebe, Bolivia $\left(11^{\circ} 00^{\prime} 00^{\prime \prime} \mathrm{S}, 67^{\circ} 25^{\prime} 00^{\prime \prime} \mathrm{W}\right)$.
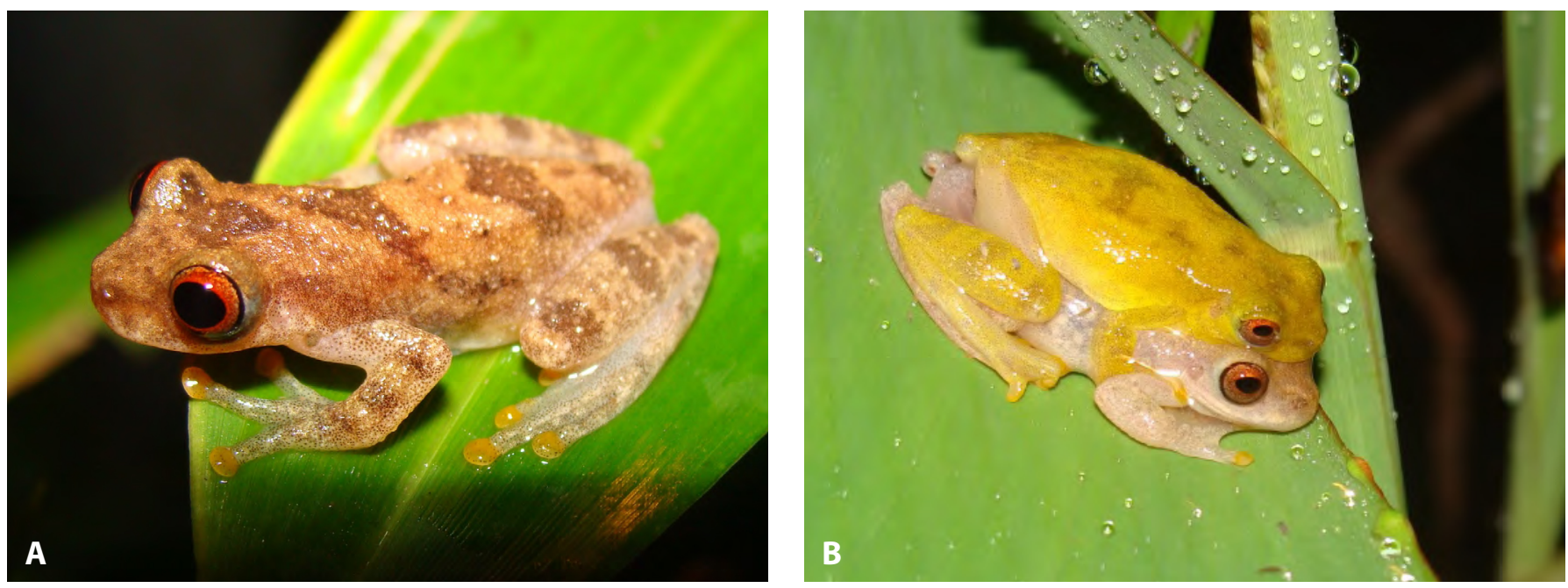

Figure 2. A: Dorsolateral view of Dendropsophus joannae from Parque Ambiental Chico Mendes, Rio Branco - AC. B: An amplectant pair of Dendropsophus joannae from Parque Zoobotânico, Rio Branco. Photo by PRMS. 

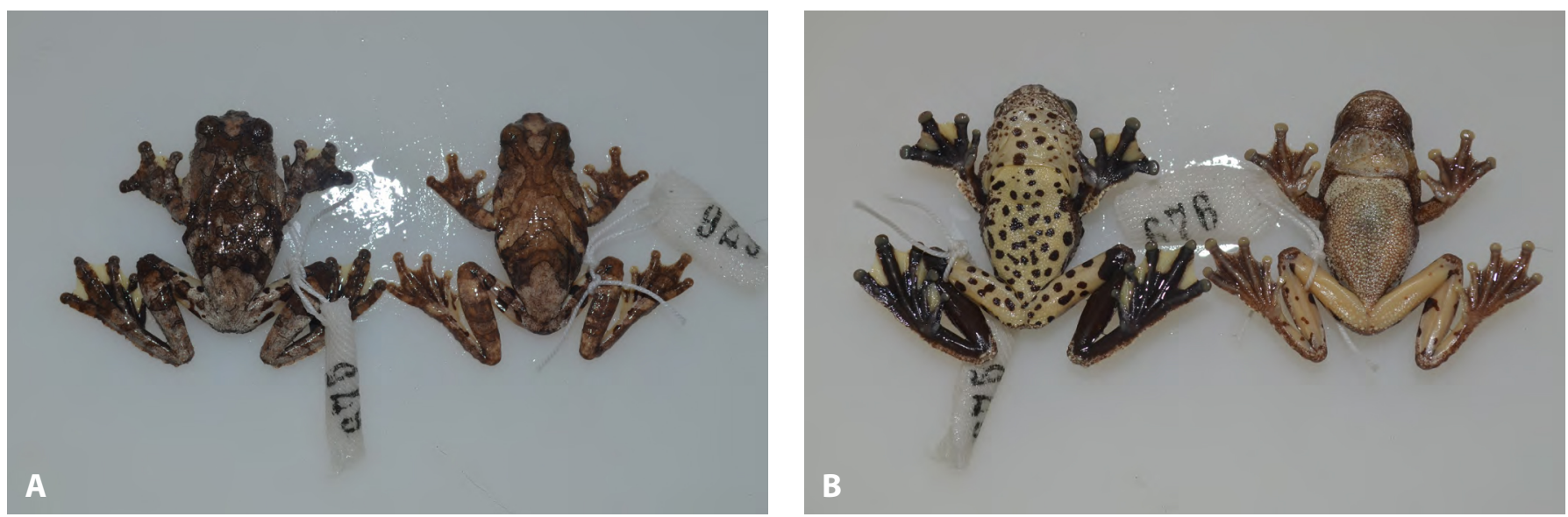

Figure 3. A: Dorsal view syntopic Dendropsophus marmoratus (left) and D. acreanus (right) from RFH. B: Ventral view of syntopic Dendropsophus marmoratus (left) and $D$. acreanus (right) from RFH. Note the yellow webbing between toes, rounded black spots and black tibia and foot in $D$. marmoratus and small gray spots on belly, orange tibia and foot, and brown webbing in D. acreanus.

Igarapé Ramon: four individuals (UFAC-RB 1419, 1429, 1431, 1435). Cruzeiro do Sul: Reserva Extrativista do Alto Juruá [REAJ hereafter]: Foz do rio Tejo: two individuals (UFAC-RB 2048, 2051). Foz do Rio Breu: two individuals (UFAC-RB 2279, 2396). Caminho do Arara: three individuals (UFAC-RB 2528-2530). Lago da Pólvora: two individuals: (UFAC-RB 3741-3742). Rio Branco: Parque Ambiental Chico Mendes [PACM hereafter]: seven individuals (UFAC-RB 4642-4648). Área de Proteção Ambiental Raimundo Irineu Serra [APARIS hereafter]: three individuals (UFAC-RB 6218,6220-6221).

REMARKS: Venâncio et al. (2014) in an extensive work on anuran-pond community misidentified this species as Dendropsophus leali at PACM. According Köhler and Lötters (2001), Dendropsophus joannae is most similar to $D$. leali from which it is distinguished mainly by smaller size, shorter snout, more protuberant eyes, more tuberculate dorsal skin, and a red inner iris in life. Barrio-Amorós and Neira (2004) reported this species to Tambopata, Peru. Based in our records, near the Peruvian border at rio Juruá, we are confident that this species could reach into river Ucayali drainage. The known distribution of Dendropsophus joannae is extended to Acre in ca. $680 \mathrm{~km}$ northwest in a straight line from Cobija (Köhler and Lötters 2001).

\section{Dendropsophus marmoratus (Laurenti, 1768)}

\section{Figure 3}

Porto Acre: Reserva Florestal Humaitá [RFH hereafter]: one individual (UFAC-RB 0676). Porto Walter: two individuals (UFAC-RB 6268-6269).

REMARKS: This species is easily confused with Dendropsophus acreanus, a slightly smaller species having fine black reticulations on the venter and limbs with yellow concealed surfaces, whereas $D$. marmoratus has bold black mottling on the venter and limbs with orange concealed surfaces (Duellman 2005). It was illustrated in Souza (2009), plate 19 as Dendropsophus acreanus. Dendropsophus marmoratus differs from $D$. acreanus in the less projecting eyes, the expanded web between fingers and toes, and the ventral coloration of abdomen (large blacks markings versus no markings with interstices between granules black) and ventral surface hind limbs (usually black versus pale, with a few black blotches). Although Bokermann (1964) stated that there are no localities where both Dendropsophus

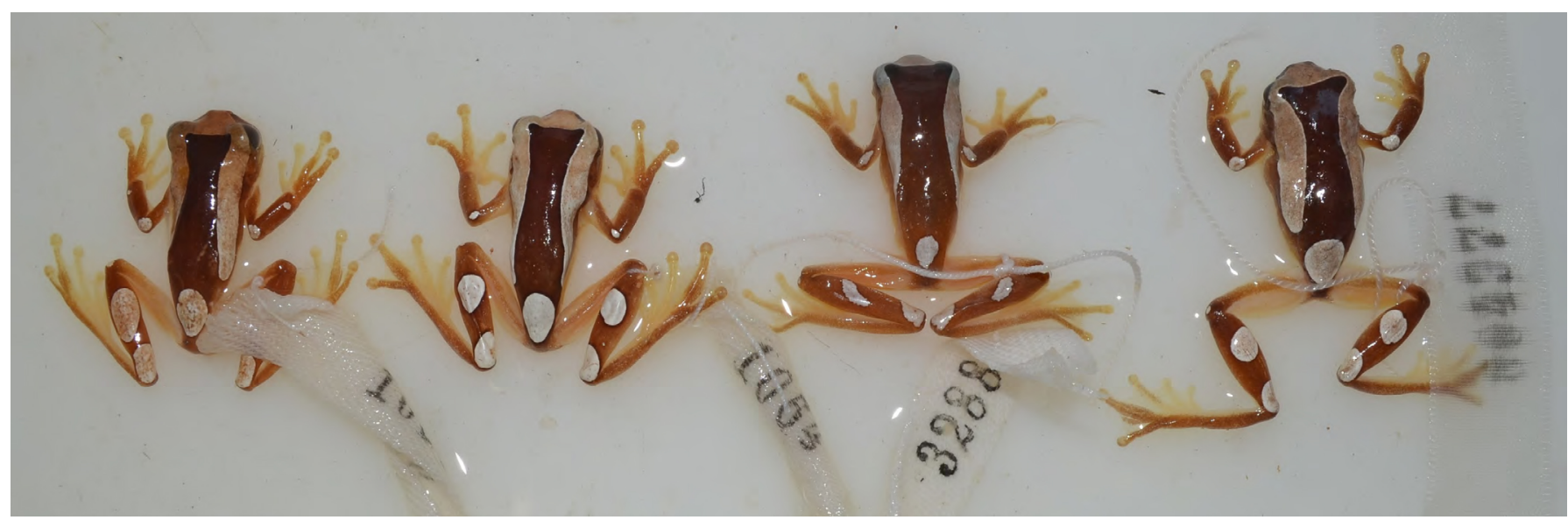

Figure 4. Dorsal view of Dendropsophus salli. Note the white spot on elbow and knee. 

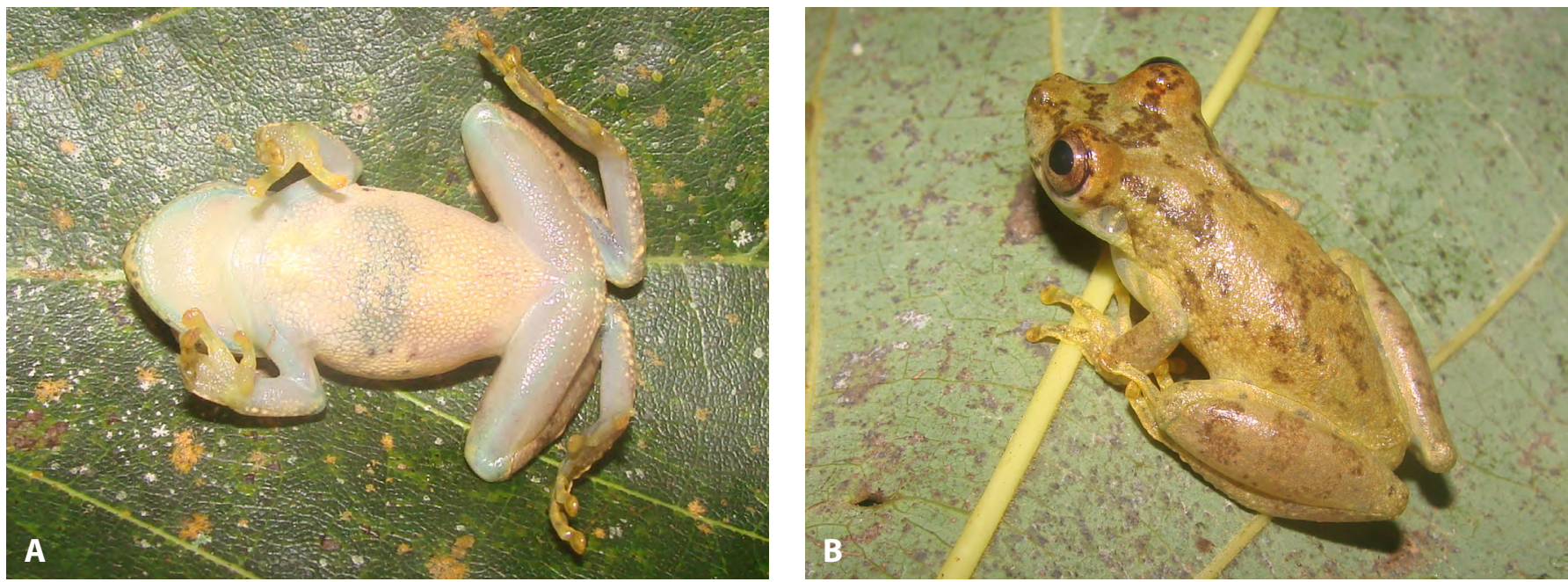

Figure 5. A: Ventral view of Scinax ictericus from Reserva Florestal Humaitá (not collected). B: Dorsal view of Scinax ictericus from Reserva Florestal Humaitá (not collected). Photo by MBS.

marmoratus and D. acreanus occur together, we are able to find both syntopically at Reserva Florestal Humaitá. These records extend the known distribution $140 \mathrm{~km}$ north of Nacebe (Moravec and Aparício 2004) in Bolivia.

Dendropsophus salli Jungfer, Reichle \& Piskurek, 2010 Figure 4

Porto Acre: Reserva Florestal Humaitá: two individuals (UFAC-RB (1064, 1066). Feijó: Rio Jurupari: one individual (UFAC-RB 4977). Rondônia: Espigão do Oeste: Fazenda Jaburi: one individual (UFAC-RB 3288).

REMARKS: this species is known to its type locality in Bolivia (Nacebe) and listed at appendix 1 from Acre, municipality of Tarauacá (MZUSP 116707-19) by Orrico et al. (2014). Thus, our records extend the species' known distribution to Espigão do Oeste, Rondônia. According to its original description (Jungfer et al. 2010), this species was previously confused with Dendropsophus bifurcus. Dendropsophus salli is now recorded to Rondônia, 780 $\mathrm{km}$ northeast of its type locality in Provincia Ballivian, Departamento Beni, Bolivia.

\section{Scinax ictericus (Duellman \& Wiens, 1993)}

Figure 5

Mâncio Lima: Parque Nacional da Serra do Divisor: Gibraltar: 12 individuals (UFAC-RB 1517-1528, 1811). Cruzeiro do Sul: Parque Nacional da Serra do Divisor: Santo Antônio: six individuals UFAC-RB (3848-3853). Reserva Extrativista Alto Juruá: Foz do Rio Tejo (UFAC-RB (2068-2070). Foz do rio Breu: six individuals (UFAC-RB 2348-2349, 2409-2412). Juazeiro: two individuals (UFAC-RB 2866, 2868). Rio Branco: Parque Zoobotânico da Universidade Federal do Acre: five individuals (UFAC-RB 3144, 3146-3147, 3149-3150).

REMARKS: According to its original description (Duellman and Wiens 1993), Scinax ictericus is known from its type and additional localities in Peru. This species was assigned as Scinax cruentommus, S. funereus, or S. ruber in UFAC-RB. Scinax ictericus is now known from Gibraltar, Brazil, ca. 395 northwest in a straight line from Balta, Peru, the closest site known between several localities at elevations of less than $300 \mathrm{~m}$ in the drainages of the Rio Purus and Rio Madre de Dios in southern Peru where it occurs (Duellman and Wiens 1993).

Scinax iquitorum Moravec, Arista, Pérez \& Lehr, 2009 Figure 6

Plácido de Castro: Reserva Extrativista Porto Dias [REPD hereafter]: two individuals (UFAC-RB 1228-1229).

REMARKS: We follow the characters proposed by Moravec et al. (2009) for species identification: (1) male SVL $35.0 \mathrm{~mm}$, females $38.5 \mathrm{~mm}$; (2) snout rounded, not acuminate in dorsal and lateral views; (3) ulnar and tarsal tubercles indistinct (inconspicuous traces of small tubercles can be detected in proximal outer edge of tarsus); (4) tubercles absent on heel; (5) tubercles absent on lower jaw; (6) skin on dorsum slightly to coarsely shagreen; (7) in life, dorsum light olive-green to brown; (8) in life, flanks bright yellow with distinct round black spots becoming gradually larger from axillae to groin; (9) in life, concealed surfaces of legs black; (10) in life, iris gold to bronze with irregular dark reticulation. Our record extends the known distribution $670 \mathrm{~km}$ southeast from Santa Luzia, municipality of Cruzeiro do Sul, Brazil (Machado et al. 2015).

\section{Scinax pedromedinae (Henle, 1991)}

Figure 7

Porto Acre: Reserva Florestal Humaitá: one individual (UFAC-RB 1054). Plácido de Castro: Reserva Extrativista Porto Dias: one individual (UFAC-RB 1196). Cruzeiro do Sul: Parque Nacional da Serra do Divisor: foz do Rio Branco: three individuals (UFAC-RB 1808-1810). Foz do rio Breu: two individuals (UFAC-RB 2345-2346). Manuel 
Urbano: Parque Estadual Chandless: one individual (UFAC-RB 4912). Mâncio Lima: Área de Relevante Interesse Ecológico Japiim-Pentecoste [ARIE hereafter]:
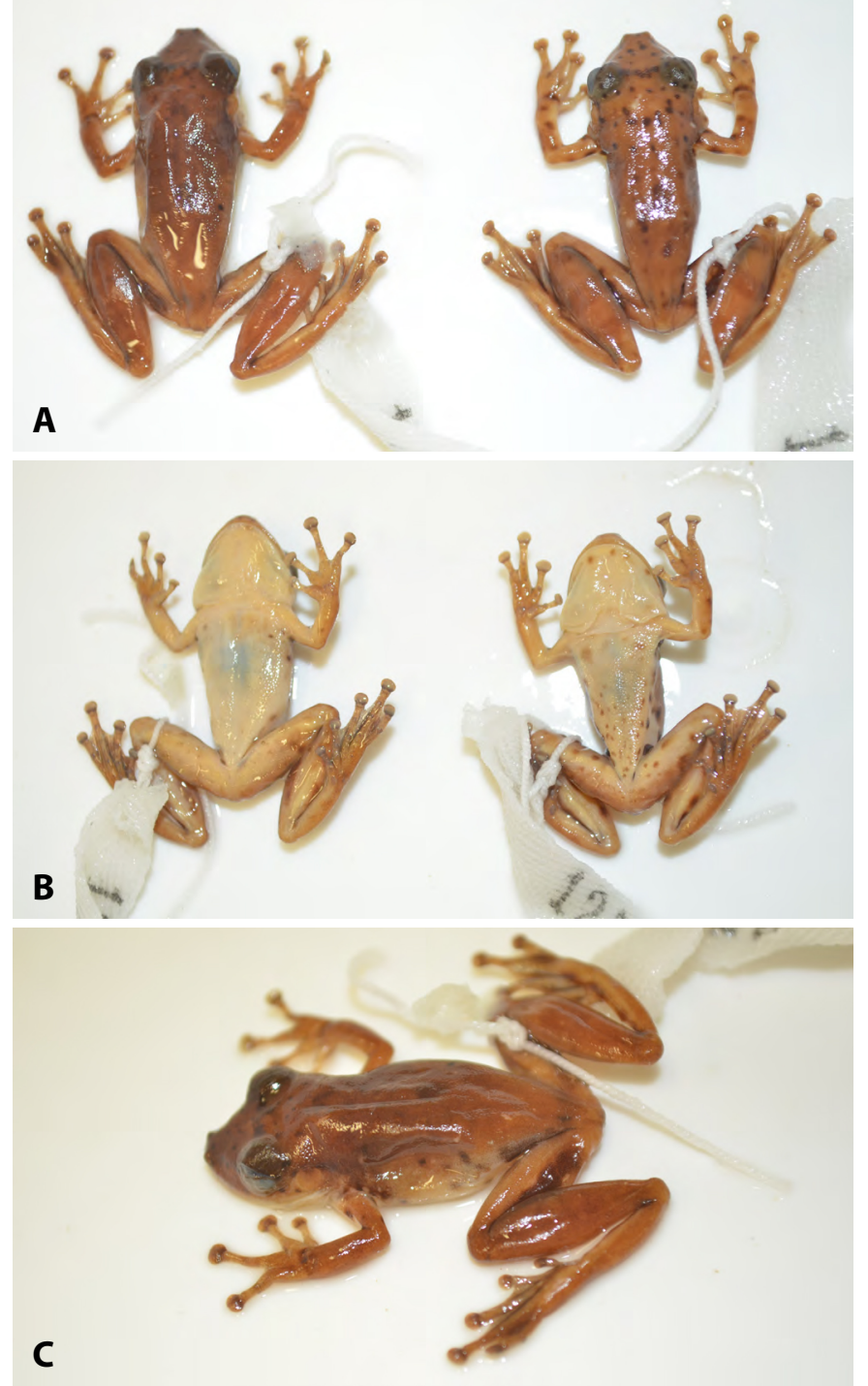

Figure 6. A: Dorsal view of Scinax iquitorum showing small spots on the forelimbs. B: Ventral view of Scinax iquitorum showing small spots on chin. C: Lateral view of Scinax iquitorum showing the spots on the flanks and dark posterior surface of thighs.

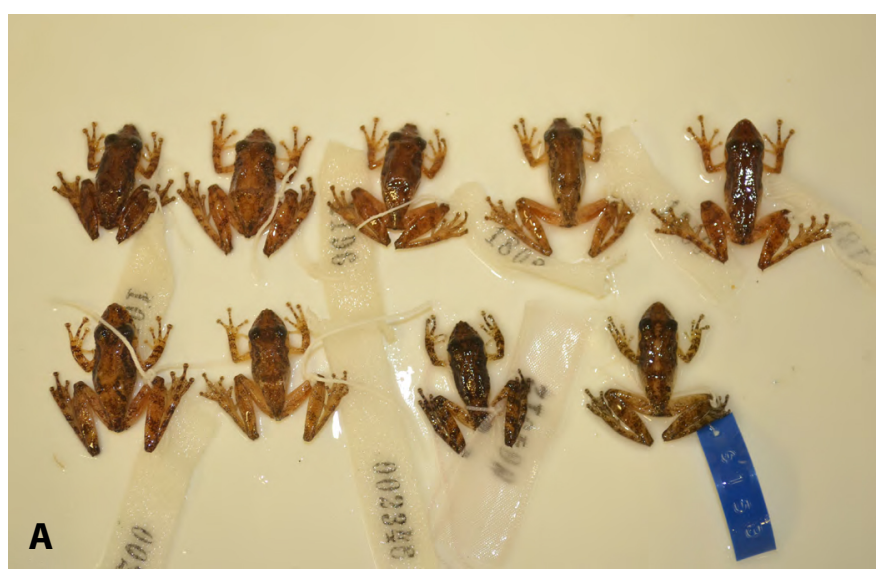

one individual (UFAC-RB 6153).

REMARKS: we fill a gap in the distribution record of Scinax pedromedinae: REAJ, PNSD and ARIE specimens are between Pucallpa area in Peru (Duellman and Wiens 1993) and Porto Alegria, Loreto, Peru (Hoogmoed and Ávila-Pires 2011), extending the known distribution of the species ca. $145 \mathrm{~km} \mathrm{~N}$ and $495 \mathrm{~km}$ southwest, respectively. PEC, REPD and RFH specimens are located between Pakitza (Departamento Madre de Dios) and Nacebe (Departamento Pando) the closest localities in Peru, and extends ca. $140 \mathrm{~km}$ north of its distribution (Moravec and Aparicio 2004; Hoogmoed and Ávila-Pires 2011).

\section{Teratohyla midas (Lynch \& Duellman, 1973)}

Figure 8

Mâncio Lima: Parque Nacional da Serra do Divisor: Igarapé Ramon: six individuals (UFAC-RB 3630-3635). Peru: Loreto: Parque Nacional Sierra del Divisor: Contamana: one individual (UFAC-RB 3616) .

Remarks: This species was misidentified as Centrolene sp. and illustrated in the plate 8 from Souza (2009). Recently, this species was found near Andes at San Martin and Pongo de Rentema sites in Peru (Twomey et al. 2014) suggesting that it is not restricted to lowland habitats. This record of Teratohyla midas decrease the gap in the distribution $590 \mathrm{~km}$ west from Boca do Acre region, Amazonas (França and Venâncio 2010), 520 km northwest from Pakitza, Madre de Dios, Peru (Duellman 2005) and $540 \mathrm{~km}$ south from Letícia, Colômbia (Lynch 2005).

The new distributional records reveal the importance of surveys in fragmented areas, since that many species were collected in this habitat, including the open forests with bamboo, a phytophysiognomy poorly studied concerning herpetofauna. Souza (2009) related more than 100 species throughout western portion of Acre state into two large conservation units (PNSD and REAJ) with different degrees of human occupation (integral protection in the former, and sustainable use in the last one). Major taxonomic changes were followed

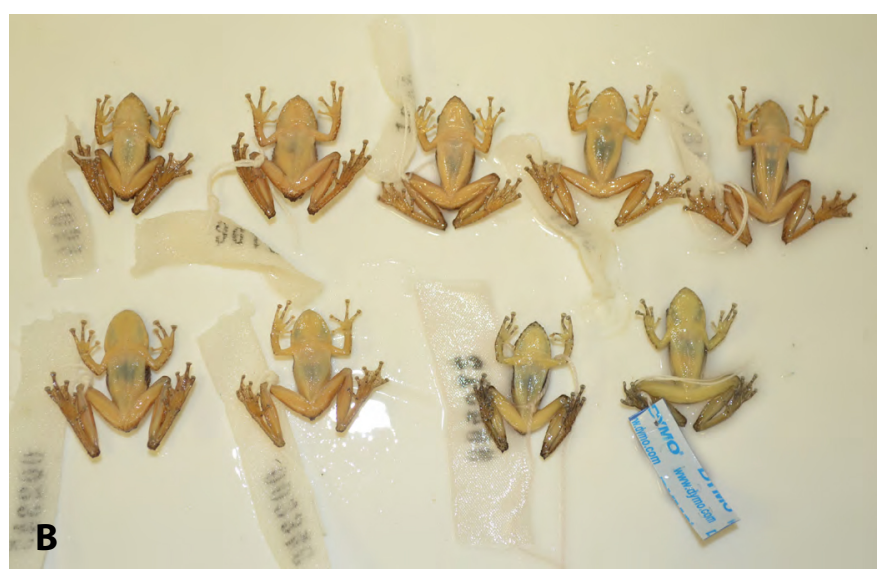

Figure 7. A: Dorsal view of Scinax pedromedinae showing no spots on the posterior surfaces of thighs. B: Ventral view of Scinax pedromedinae showing dark plantar surfaces. 


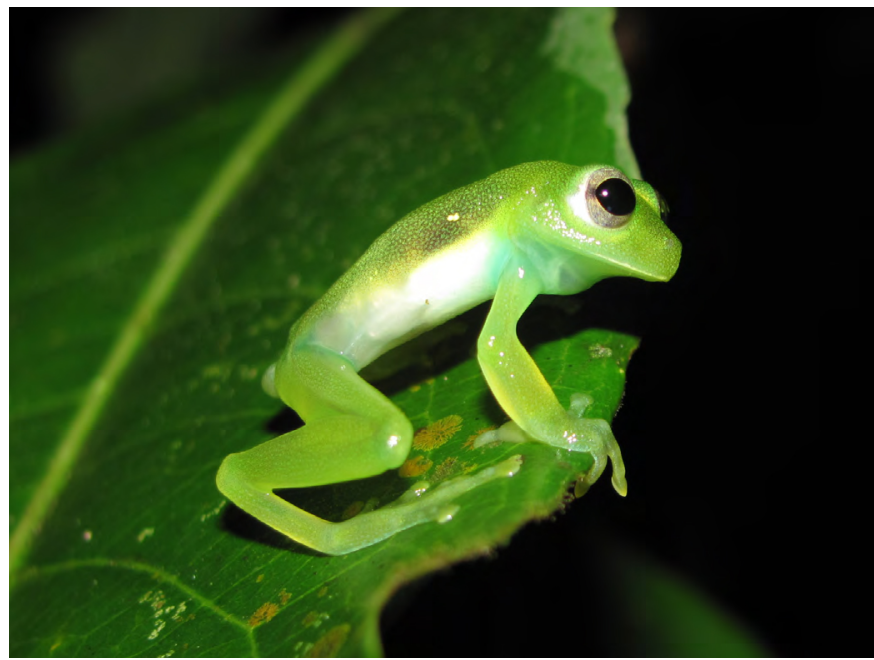

Figure 8. Dorsolateral view of Teratohyla midas. Photo by PRMS

in Souza (2009); however, it lacks detailed information for species described after 2000.

Many species mentioned here are restricted to western portion of Amazon and Andes slopes are expected to occur in Brazil. Further studies on herpetofauna of open forests with bamboo are needed. Currently, either some candidate species remains unnamed, whereas named species wait synonymization or revalidation in light of integrative taxonomy (Ortega-Andrade and Venegas 2014). The genera Scinax and Dendropsophus still are challenging and we hope that herpetologists pay attention with small treefrogs, and detail every species in life including acoustic and behavioral characters (natural history notes) before assigned a name to checklist, because they are abundant and very common, but its taxonomy is very hard, mainly to fix after preservation leading to misidentification and unwarranted descriptions.

\section{ACKNOWLEDGEMENTS}

Evan Twomey, César Luis Barrio-Amorós and one anonymous reviewer made useful comments in the earlier versions of this manuscript and provided relevant literature. Evan Twomey also gently helped with the English version of this manuscript. Jhon Jairo LópezRojas helped with the map. PRMS is a doctoral fellowship supported by Coordenação de Aperfeiçoamento de Pessoal de Nível Superior (CAPES). We are grateful to SISBIO by permits \#19347-1, \#27290-1 and \#37974-1.

\section{LITERATURE CITED}

Barrio-Amorós, C.L. and D.R. Neira. 2004. Dendropsophus joannae (NCN) Geographic Distribution. Herpetological Review 35(4): 404

Bokermann, W.C.A. 1964. Notes on treefrogs of the Hyla marmorata group with description of a new species (Amphibia, Hylidae). Senckenbergiana Biologica 45: 243-254.

Brown, J.L., E. Twomey, A. Amézquita, M.B. Souza, J.P. Caldwell, S. Lötters, R. von May, P.R. Melo-Sampaio, D. Mejía-Vargas, P. Perez-Peña, M. Pepper, E.H. Poelman, M. Sanchez-Rodriguez and K. Summers. 2011. A taxonomic revision of the Neotropical poison frog genus Ranitomeya (Amphibia: Dendrobatidae). Zootaxa 3083:1-120. http://www.mapress.com/zootaxa/2011/2/ zto3083p120.pdf

De la Riva, I. and W.E. Duellman. 1997. The identity and distribution of Hyla rossalleni Goin. Amphibia-Reptilia 18(4): 433-436. doi: 10.1163/156853897Xoo486

De la Riva, I., J. Köhler, S. Lötters and S. Reichle. 200o. Ten years of research on Bolivian amphibians: updated checklist, distribution, taxonomic problems, literature and iconography. Revista Española de Herpetología 14: 19-164.

Duellman, W.E. 2005. Cuzco Amazónico: The lives of amphibians and reptiles in an Amazonian rainforest. Comstock Publishing Associates, Cornell University Press, Ithaca.

Duellman, W.E. and J.J. Wiens. 1993. Hylid frogs of the genus Scinax Wagler, 1830, in Amazonian Ecuador and Peru. Occasional Papers of the Museum of Natural History University of Kansas 153: 1-57. http://biodiversitylibrary.org/page/4468136

França, F.G.R. and N.M. Venâncio. 2010. Reptiles and amphibians of poorly known region in southwest Amazonia. Biotemas 23: 71-84. https://periodicos.ufsc.br/index.php/biotemas/article/ download/2175-7925.2010v23n3p71/14358

Hoogmoed, M.S. and T.C.S. Ávila-Pires. 2011. On the presence of Scinax pedromedinae (Henle, 1991) (Amphibia: Anura: Hylidae) in Amazonian Brazil and northern Peru. Boletim do Museu Paraense Emílio Goeldi Ciências Naturais 6: 263-271. http:// scielo.iec.pa.gov.br/pdf/bmpegcn/v6n3/v6n3ao3.pdf

Jungfer, K.-H., S. Reichleand O. Piskurek. 2010. Description of a new cryptic southwestern Amazonian species of leaf-gluing treefrog, genus Dendropsophus (Amphibia: Anura: Hylidae). Salamandra 46:204-213. http://www.salamandra-journal.com/index.php?option=com docman\&task=doc_download\&gid=222\&Itemid=59

Köhler, J. and S. Lötters. 2001. A new species of minute Hyla from the southwestern Amazon Basin (Amphibia, Anura, Hylidae). Studies on Neotropical Fauna and Environment 36(2): 105-112. doi: 10.1076/snfe.36.2.105.2135

Lehr, E., C.P. Torres and J. Suárez. 2007. A new species of arboreal Eleutherodactylus (Anura: Leptodactylidae) from the Amazonian lowlands of central Peru. Herpetologica 63(1): 94-99. doi: 10.1655/0018-0831(2007)63[94:ANSOAE]2.0.CO;2

López-Rojas, J.J., W.P. Ramalho, M.S. Susçuarana and M.B. Souza. 2013. Three new records of Pristimantis (Amphibia: Anura: Craugastoridae) for Brazil and a comment of the advertisement call of Pristimantis orcus. Check List 9(6): 1548-1551. http://www. checklist.org.br/getpdf?NGDo62-13

Lynch, J.D. 2005. Discovery of the richest frog fauna in the world an exploration of the forests to the north of Leticia. Revista de la Academia Colombiana de Ciencias Físicas, Exatas y Naturales 29: 581-588.

Machado, D.C., R.A. Machado, D. Paiva and J. Moravec. 2015. First record of Scinax iquitorum Moravec,Tuanama, Pérez-Peña \& Lehr, 2009, from Brazil. Herpetozoa 27 (3/4): 189-19o.

Melo-Sampaio, P.R. and M.B. Souza. 2009. Geographic distribution: Ranitomeya biolat. Herpetological Review 40(4): 447.

Melo-Sampaio, P.R. and M.B. Souza. 2010. Amphibia, Anura, Strabomantidae, Pristimantis reichlei Padial and De la Riva, 2009: First record from Brazil, southwestern Amazonia. Check List 6(3): 385-386. http://www.checklist.org.br/getpdf?NGDo20-10

Melo-Sampaio, P.R. and C.M.B. Oliveira. 2013. Teratohyla midas (Santa Cecília Cochran Frog): Geographical Distribution. Herpetological Review 44(1): 104.

Moravec, J. and J. Aparício. 2004. Notes on the herpetofauna of Nacebe (Provincia Abuna, Departamento Pando, Bolivia). Časopis Národního Muzea 173: 13-28.

Moravec, J., J. Aparício and J. Köhler. 2006. A new species of tree frog, genus Dendropsophus (Anura: Hylidae), from the Amazon 
of northern Bolivia. Zootaxa 1327: 23-40. http://www.mapress. com/zootaxa/2006/zto1327po4o.pdf

Moravec, J., J. Aparício, M. Guerrero-Reinhard, G. Calderón and J. Köhler. 2008. Diversity of small Amazonian Dendropsophus (Anura: Hylidae): another new species from northern Bolivia. Zootaxa 1918: 1-12. http://www.mapress.com/zootaxa/2008/2/ zto1918po12.pdf

Moravec, J., I.A. Tuanama, P.A. Pérez-Peña and E. Lehr. 2009. A new species of Scinax (Anura: Hylidae) from the area of Iquitos, Amazonian Peru. South American Journal of Herpetology 4(1): 9-16. doi: 10.2994/057.004.0102

Moravec, J., J. Aparicio, M. Guerrero-Reinhard and G. Calderon. 2011. Anuran species richness in the Departamento Pando, Bolivia; p. 47-57, in: Schuchmann, K.L., (ed.) Tropical vertebrates in a changing world. Museum Alexander König, Bonn.

Orrico, V.D.G., P.L.V. Peloso, M.J. Sturaro, H.F. Silva-Filho, S. NeckelOliveira, M. Gordo, J. Faivovich and C.F.B. Haddad. 2014. A new "Bat-Voiced" species of Dendropsophus Fitzinger, 1843 (Anura, Hylidae) from the Amazon Basin, Brazil. Zootaxa 3881: 341-361. doi: 10.11646/zootaxa.3881.4.3

Ortega-Andrade, H.M. and P.J. Venegas. 2014. A new synonym for Pristimantis luscombei (Duellman and Mendelson 1995) and the description of a new species of Pristimantis from the upper
Amazon basin (Amphibia: Craugastoridae). Zootaxa 3895: 31-57. Rodríguez, L.O. and W.E. Duellman. 1994. Guide to the frogs of the Iquitos region, Amazonian Peru. University of Kansas Natural History Museum, Special Publication 22: 1-80.

Souza, M.B. 2009. Anfíbios: Reserva Extrativista do Alto Juruá e Parque Nacional da Serra do Divisor, Acre. Campinas: IFCH. 77 pp. +32 plates.

Twomey, E., J. Delia and S. Castroviejo-Fisher. 2014. A review of Northern Peruvian glassfrogs (Centrolenidae), with the description of four new remarkable species. Zootaxa 3851:1-87. doi: 10.11646/zootaxa.3851.1.1

Venâncio, N.M., A.P. Lima, M.B. Souza and W.E. Magnusson. 2014. Between-year consistency of anuran assemblages in temporary ponds in a deforested area in Western Amazonia. Herpetological Journal 24(3): 155-160.

Authors' contribution statement: PRMS conceived the idea, PRMS and MBS collected the data, PRMS wrote the text, and PRMS and MBS made the photographs.

Received: 26 February 2015

Accepted: 2 June 2015

Academic editor: Camila Both 